\title{
Survey of uranium in drinking water sources in India: interim observations
}

\author{
S. K. Sahoo ${ }^{1}$, S. K. Jha ${ }^{1,2, *}$, V. N. Jha ${ }^{1}$, A. C. Patra ${ }^{1}$ and M. S. Kulkarni ${ }^{1,2}$ \\ ${ }^{1}$ Health Physics Division, Bhabha Atomic Research Centre, Trombay, Mumbai 400 085, India \\ ${ }^{2}$ Homi Bhabha National Institute, Trombay, Mumbai 400 085, India
}

A nationwide survey is being conducted for mapping uranium content in drinking water sources across India, in association with local educational and research institutions. For this, an optimum grid size of $6 \times 6 \mathrm{sq} . \mathrm{km}$ was selected based on the international practices for geochemical mapping. About 55,554 surface as well as groundwater samples, used for drinking purpose, were collected covering approximately $1.2 \times 10^{6} \mathrm{sq} . \mathrm{km}$. Light emitting diode-based fluorimeter having wide dynamic range and $0.2 \mu \mathrm{g} \mathrm{I}^{-1}$ lower detection limit was used for direct measurement of uranium content in the water samples. Uranium was detected in $83.6 \%$ of all the collected water samples. The geometric mean of uranium concentration in surface and groundwater samples was found to be $0.8 \mu \mathrm{g} \mathrm{I}^{-1}$ (range: $\leq 0.2-22 \mu \mathrm{g} \mathrm{I}^{-1}$ ) and $2.1 \mu \mathrm{g} \mathrm{l}^{-1}$ (range: $\leq 0.2-4918 \mu \mathrm{g} \mathrm{I}^{-1}$ ) respectively. Out of 12 water quality parameters measured to understand the geochemical processes governing uranium content in water sources, eight were found to exceed the acceptable limits set by the Bureau of Indian Standards for drinking water. The parameters sulphate, chloride, nitrate, fluoride, total dissolved solids, alkalinity and hardness exceeded their limits by $4.2 \%, 12.9 \%, 14 \%, 20.5 \%$, $34.3 \%, 45 \%$ and $51.6 \%$ respectively. Uranium content in $98 \%$ of groundwater samples was found to be less than the national limit set by the Atomic Energy Regulatory Board for radiological safety. Dissolved uranium content in groundwater samples showed an upward trend with total dissolved solids and depth of water sources. No surface water samples exceeded the prescribed regulatory limit.

Keywords: Drinking water sources, fluorimeter, surface and groundwater, uranium, water quality parameters.

INDIA is the largest user of groundwater in the world, consuming about $25 \%$ of global groundwater resources ${ }^{1}$. Groundwater resources in India contribute nearly $62 \%$ and $85 \%$ of agriculture and drinking water requirements respectively ${ }^{2}$. According to a report by the Central Ground Water Board (CGWB) ${ }^{2}, 17 \%$ of 6881 assessment units (blocks/watersheds/mandals/talukas/firka) categorized based on the stage of groundwater extraction, have

\footnotetext{
*For correspondence. (e-mail: skjha@barc.gov.in)
}

been identified as overexploited ${ }^{2}$. The overexploitation of groundwater resources has been observed in all types of aquifers in the country. This includes soft-rock aquifer system in Punjab, Haryana and western Uttar Pradesh, complex heterogeneous aquifer systems in Rajasthan and Gujarat, and low potential hard-rock aquifer systems in Karnataka, Andhra Pradesh, Tamil Nadu and Maharashtra ${ }^{2}$. Overexploitation of groundwater resources is one of the reasons for geogenic contaminants like arsenic, fluoride, salinity, uranium, etc. in the water sources at several places. Geogenic processes coupled with overexploitation of groundwater have changed the water quality in different resources ${ }^{3}$.

Uranium, a naturally occurring heavy element having low specific activity $(25 \mathrm{~Bq} / \mathrm{mg})$, is present in every compartment of the earth's secondary environment. Uranium concentration varies in the range $2-10 \mathrm{mg} \mathrm{kg}^{-1}$ in rocks globally ${ }^{4}$. Natural uranium has three isotopes, namely ${ }^{238} \mathrm{U},{ }^{235} \mathrm{U}$ and ${ }^{234} \mathrm{U}$ having $99.27 \%, 0.72 \%$ and $0.005 \%$ mass abundance respectively ${ }^{4}$. Uranium is a redox-sensitive element and mainly exists in two oxidation states, i.e. +4 and +6 under anoxic and oxic conditions respectively. Uranium of higher oxidation state is more stable due to its inert electronic configuration. It is known that uranium combines with oxygen to form the uranyl ion $\left(\mathrm{UO}_{2}^{++}\right)$, and reacts with different anions present in the natural aquatic system. Under conducive oxic condition, uranium leaches out of the host rock and enters the groundwater, governed by complex physicochemical processes. Under reducing condition (negative redox potential, $E_{\mathrm{h}}$ ), uranium gets precipitated from groundwater ${ }^{4}$.

Natural and anthropogenic activities/sources such as geogenesis, host rock-water interaction, run-off water, industrial effluents, phosphatic fertilizers, fossil fuels, etc. contribute to uranium content in various water resources. Uranium is a nephrotoxic element and can have adverse impact at very high concentrations ${ }^{5}$. However, according to some studies, the adverse health effects are not directly linked to its content in drinking water ${ }^{6}$. In spite of higher uranium content $\left(5.6-3410 \mu \mathrm{g} \mathrm{l}^{-1}\right)$ in drinking water of drilled wells in southern Finland, no clear clinical symptoms were reported among the exposed population ${ }^{6}$. Globally, there are many contradictory findings on the health effects due to uranium content in 
Table 1. List of participating educational and research institutions in the present study

Institution

JNTUA College of Engineering, Anantapur, Andhra Pradesh

PRAGATI Engineering College, East Godavari, Andhra Pradesh

NERIST, Nirjuli, Itanagar, Arunachal Pradesh

Tezpur University, Assam

National Institute of Technology, Patna, Bihar

Central University of Bihar, Patna, Bihar

A. N. College, Patna, Bihar

Bhilai Institute of Technology, Raipur, Chhattisgarh

Bhilai Institute of Technology, Durg, Chhattisgarh

National Institute of Technology, Raipur, Chhattisgarh

Saurashtra University, Rajkot, Gujarat

M. K. Bhavnagar University, Bhavnagar, Gujarat

MS University of Baroda, Gujarat

North Gujarat University, Patan, Gujarat

Gujarat University, Ahmedabad, Gujarat

Navjivan Science College, Dahod, Gujarat

Maharshi Dayanand University, Rohtak, Haryana

Indian Institute of Technology Mandi, Himachal Pradesh

Birla Institute of Technology Mesra, Jharkhand

R.V. College of Engineering, Bengaluru, Karnataka

Centre for Water Resources Development and Management Kozhikode, Kerala

Mahatma Gandhi University, Kottayam, Kerala

Fatima Mata National College, Quilon, Kerala

Dr Harisingh Gour Central University, Sagar, Madhya Pradesh

Defence Institute of Advanced Technology, Pune, Maharashtra

SIES (Nerul) College of ASC, Nerul, Navi Mumbai, Maharashtra

Dr B.A.M.U. University, Aurangabad, Maharashtra

Shivaji University, Kolhapur, Maharashtra

Shri Shivaji College of Arts, Commerce and Science, Akola, Maharashtra

K.I.T.S. Ramtek, Nagpur, Maharashtra

Manipur Central University Imphal West, Manipur

Mizoram University, Aizawl, Mizoram

Jawaharlal Nehru University, New Delhi

Bhaskaracharya College of Applied Sciences, University of Delhi, New Delhi

KIIT University, Bhubaneswar, Odisha

Stewart College, Cuttack, Odisha

National Institute of Technology, Rourkela, Odisha

Ravenshaw University, Cuttack, Odisha

Institute of Technical Education and Research, S ‘O’A University, Odisha

Guru Nanak Dev University, Amritsar, Punjab

Central University of Punjab, Bathinda, Punjab

University of Kota, Rajasthan

University of Kashmir, Srinagar

University of Madras, Chennai, Tamil Nadu

Sastra University, Thanjavur, Tamil Nadu

National Engineering College, Thoothukudi, Tamil Nadu

University of Madras, Chennai, Tamil Nadu

Presidency College, Chennai, Tamil Nadu

National Geophysical Research Institute, Hyderabad, Telangana

Rajiv Gandhi Institute of Petroleum Technology, Rae Bareli, Uttar Pradesh

L. S. M. G. P. G. College Pithoragarh, Uttrakhand

Jadavpur University, Kolkata, West Bengal

drinking water, which makes it a more complex and challenging problem ${ }^{5,7}$. It is therefore a matter of concern to regulatory agencies, and entails monitoring of uranium in various water sources.

There are many places in the world where elevated levels of uranium in drinking water are attributed to geogenic causes ${ }^{8}$. In South Korea, a national survey for groundwater showed that uranium content varied from $<0.01$ to $3610 \mu \mathrm{g}^{-1}$, with median value of $0.7 \mu \mathrm{g} \mathrm{l}^{-1}$ (ref. 9). Nationwide studies carried out in Switzerland and
Kosovo, reported uranium content in groundwater to be in the range $0.05-92.02 \mu \mathrm{g} \mathrm{l}^{-1}$ (median value of $0.77 \mu \mathrm{g} \mathrm{l}^{-1}$ ) and $0.012-166 \mathrm{~g} \mathrm{I}^{-1}$ (median value: $\left.1.6 \mu \mathrm{g} \mathrm{l}^{-1}\right)^{11}$ respectively. In the High Plains and Central Valley aquifers in USA, uranium content in water samples was reported to be $\quad<0.5-2674 \mu \mathrm{g} \mathrm{l}^{-1}$ (median value: $5.1 \mu \mathrm{g} \mathrm{l}^{-1}$ ) and $<0.5-5400 \mu \mathrm{g} \mathrm{l}^{-1}$ (median value: $45 \mu \mathrm{g} \mathrm{l}^{-1}$ ) respectively ${ }^{12}$. In India, uranium content in the groundwater in Punjab, Chikkaballapur in Karnataka and Lalbarra region of Madhya Pradesh was found to be $<0.02-685,2.4-1443$ 
and $217-4500 \mu \mathrm{g} \mathrm{l}^{-1}$ respectively $^{4,13-15}$. A recent study reported the presence of high uranium content in groundwater in 16 states of India ${ }^{16}$. However, this study is based on limited sample density and random sample collection. For example, in Gujarat, Rajasthan, Punjab and Haryana, only 98, 226, 46 and 13 samples respectively, were analysed; and only one sample each from Maharashtra, Uttar Pradesh, Chhattisgarh and Odisha was analysed.

In order to address the public concerns about uranium in potable water sources, a nationwide survey is being conducted by the Bhabha Atomic Research Centre (BARC), Department of Atomic Energy (DAE), Mumbai with participation from local educational and research institutions (Table 1) for mapping uranium content in drinking water sources. The interim observations are reported in this article.

\section{Sampling}

The objective of the present survey is to develop a national reference database and determine the background value of uranium in drinking water. Analysis of uranium and other water quality parameters were chosen carefully to correlate the variation of the uranium content in water samples. The strategy for the survey of uranium content and other water quality parameters was based on the guidelines of geochemical mapping designed by the International Union of Geological Sciences (IUGS) Commission $^{17}$. Sampling area in India was divided into optimized grid size of $6 \mathrm{~km} \times 6 \mathrm{~km}$ for systematic and unbiased sampling using latitude and longitude as reference coordinates for integration into the national map. The sampling density in the present study for better resolution was higher compared to the reported national and international geochemical studies. The optimized grid size was further divided into smaller grids when the water sample was detected to have elevated uranium content. Water samples (1 liter volume) were collected in pre-acid cleaned plastic bottles, preferably from the centre of each grid, ensuring the potability of the water source according to the ISO 5667 and IS 3025 recommendations ${ }^{18-21}$. Water samples were collected directly from borewells fitted with submersible or hand pumps, open wells, rivers, lakes, streams, canals, water supplied by municipalities and other water sources used for drinking purpose. During sampling, details regarding geographical location, source of water samples, depth of the water sources and navigation coordinates were recorded. The depth of water source in the region and that the water being sampled is used for drinking were ascertained from the nearby habitats. In situ parameters like $\mathrm{pH}$, total dissolved solids (TDS), temperature, oxidation reduction potential (ORP) and dissolved oxygen (DO) were measured and recorded according to the BIS protocol ${ }^{22-26}$. The samples were analysed for hardness and alkalinity within $24 \mathrm{~h}$ in the nearest participating laboratory, and other parameters like uranium and anions within the prescribed preservation time ${ }^{18,21}$. The site-specific information was also recorded in the uniform and customized information template. In the present study, about 55,554 water samples were collected from the representative sources across the country. Among these, 54,618 samples were collected from groundwater sources while 936 samples were collected from surface water sources, both used for drinking purpose. Figure 1 shows the sampling locations. The map was prepared using the Q-GIS platform based on the approved map of the Government of India.

\section{Analytical techniques}

In this study, uranium and 12 associated water quality parameters $(\mathrm{pH}$, TDS, temperature, ORP, DO, fluoride, chloride, nitrate, sulphate, phosphate, hardness and alkalinity) were analysed according to the protocols prescribed by national and international standards ${ }^{25,26}$. LEDbased fluorimetry technique was used for the analysis of ultra-trace levels of uranium in water samples ${ }^{27}$. An array of seven LEDs $(\lambda=410 \mathrm{~nm})$ act as the excitation source to excite uranium complex in the solution. The uranium complex fluoresces, giving four emission peaks (494, 516,540 and $565 \mathrm{~nm}$, maximum around $510 \mathrm{~nm}$ ) is measured by a photomultiplier tube $(\mathrm{PMT})^{28}$. About $5 \mathrm{ml}$ of the collected water sample was taken in a clean and

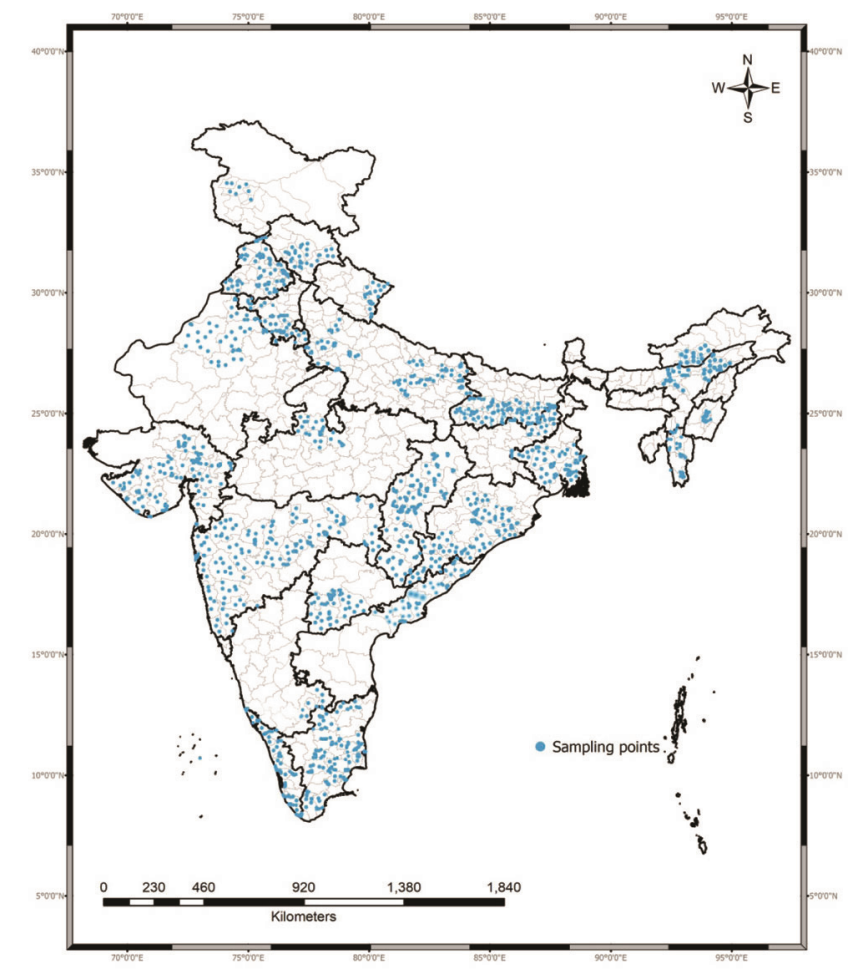

Figure 1. Sampling locations across India $(n=55,554)$. 
Table 2. Methods used for the analysis of various parameters of water samples

\begin{tabular}{llll}
\hline Parameters & Instrument/method & BIS methods & Detection limit \\
\hline Uranium & LED fluorimeter & BARC protocol & $0.2 \mu \mathrm{g} \mathrm{l}^{-1}$ \\
$\mathrm{pH}$ & pH electrode & IS 3025, Part 11 & - \\
Total dissolved solids (TDS) & Conductance & IS 3025, Part 16 & $2 \mathrm{mg} \mathrm{l}^{-1}$ \\
Dissolved oxygen (DO) & DO sensor & IS 3025, Part 38 & - \\
Redox potential (ORP) & ORP sensor & APHA 2580, 2005 & - \\
Temperature & Temperature sensor & IS 3025, Part 9 & - \\
Hardness & Titrimetry method & IS 3025, Part 21 & $10 \mathrm{mg} \mathrm{l}^{-1}$ \\
Alkalinity & Titrimetry method & IS 3025, Part 23 & $10 \mathrm{mg} \mathrm{l}^{-1}$ \\
Chloride & Ion selective electrode & IS 3025, Part 32 & $3.5 \mathrm{mg} \mathrm{l}^{-1}$ \\
Sulphate & Titration method & IS 3025, Part 24 & $5 \mathrm{mg} \mathrm{l}^{-1}$ \\
Nitrate & Titration method & IS 3025, Part 34 & $0.5 \mathrm{mg} \mathrm{l}^{-1}$ \\
Fluoride & Ion selective electrode & IS 3025, Part 60 & $0.05 \mathrm{mg} \mathrm{l}^{-1}$ \\
Phosphate & Spectrophotometer/IC & IS 3025, Part 31 & $0.02 \mathrm{mg} \mathrm{l}^{-1}$ \\
\hline
\end{tabular}

Note: Ion chromatography has been used for the analysis of anions subject to availability of the system.

Table 3. Comparison of different techniques for analysis of uranium in spiked water samples

\begin{tabular}{lcccc}
\hline $\begin{array}{l}\text { Spiked uranium } \\
\text { concentration }\left(\mu \mathrm{g}^{-1}\right)\end{array}$ & $\begin{array}{c}\text { UV-Vis } \\
\text { fluorimeter }\end{array}$ & $\begin{array}{c}\text { Laser } \\
\text { fluorimeter }\end{array}$ & $\begin{array}{c}\text { LED } \\
\text { fluorimeter }\end{array}$ & $\begin{array}{c}\text { Stripping } \\
\text { voltammetry }\end{array}$ \\
\hline 2 & $1.4 \pm 0.3$ & $1.7 \pm 0.4$ & $2.1 \pm 0.25$ & $1.6 \pm 0.2$ \\
5 & $4.6 \pm 0.9$ & $5.3 \pm 1.1$ & $4.9 \pm 0.6$ & $5.8 \pm 0.5$ \\
10 & $9.6 \pm 1.6$ & $8.6 \pm 2.8$ & $9.8 \pm 2.2$ & $10.9 \pm 1.8$ \\
30 & $31.4 \pm 3.7$ & $28.4 \pm 4.2$ & $32.4 \pm 2.8$ & $32.4 \pm 2.3$ \\
60 & $56.5 \pm 3.9$ & $63.5 \pm 5.4$ & $62.5 \pm 3.5$ & $58.5 \pm 2.9$ \\
\hline
\end{tabular}

dry suprasil quartz cuvette and $0.5 \mathrm{ml}$ of $5 \%$ sodium pyrophosphate (pH 7 adjusted with phosphoric acid) was added to $\mathrm{it}^{28}$. Sodium pyrophosphate solution acts as a fluorescence-enhancing buffer, converting the uranium species present in the sample to a single and stable phosphate complex, which also acts as a masking reagent. The fluorescence intensity is proportional to uranium content in the aqueous solution. Fluorescence from natural organic component $(\tau \sim 100 \mathrm{~ns}$ and $\lambda=400 \mathrm{~nm})$ present in the water sample is nullified by time gating technology of PMT and use of optical filters in the fluorimeter ${ }^{27-29}$. The LED fluorimeter was calibrated using standard uranium solution (certified Fluka standard) to check the linearity, sensitivity and detection limit. Details of fluorimetry and analytical techniques are given elsewhere $e^{27-29}$.

Since the chemical composition of water samples varies, positive or negative interferences are anticipated. To nullify the matrix effect due to different chemical composition of water samples, standard addition method was adopted for the analysis of water samples for uranium content. In this method, first fluorescence intensity of the water sample is measured. Uranium standard is added to the cuvette and fluorescence intensity is measured again. This process is repeated by addition of another uranium standard. A minimum three-point graph is plotted against uranium content and fluorescence intensity is measured. A linear fit is applied to the plotted graph, and it is extrapolated to estimate uranium content in the water sample ${ }^{29}$.
Twelve water quality parameters were measured according to IS 3025 protocol in all the sample ${ }^{26,30-35}$. These parameters may have an impact on the uranium geochemistry in drinking water sources. Hardness and alkalinity of the water samples were measured by titrimetry; fluoride and chloride by ion-selective electrodes and nitrate by a spectrophotometer. A fraction of samples was analysed by ion chromatography. Table 2 lists the parameters analysed in this study, the instruments and standards used and their detection limits.

\section{Quality assurance/quality control}

Strict quality assurance (QA)/quality control (QC) features were adopted in the study to ensure the quality of the data. Fixed protocol was implemented during sampling, analysis and reporting by the participating laboratories. The personnel involved in the sampling were trained for selection of sampling location, sample collection, analysis of in situ and other water quality parameters. Traceability of measurements was established with the help of certified standards. A series of data checks was incorporated like data entry, detection limit, expected range of parameters, number of significant digits, etc. The reported data were checked with empirical relationships between electrical conductivity (EC) and TDS, pH and alkalinity, and temperature and DO. All the analytical steps were documented systematically for periodic review 
Table 4. Descriptive statistics of uranium and water quality parameters of surface water samples

\begin{tabular}{|c|c|c|c|c|c|c|c|c|c|c|}
\hline Parameters & Minimum & Maximum & Median & Mode & Mean & $\begin{array}{l}\text { Standard } \\
\text { deviation }\end{array}$ & $\begin{array}{c}\text { Geometric } \\
\text { mean }\end{array}$ & $\begin{array}{c}\text { Geometric } \\
\text { SD }\end{array}$ & Skewness & Kurtosis \\
\hline $\mathrm{pH}$ & 5.0 & 8.6 & 7.5 & 7.6 & 7.51 & 0.56 & 7.5 & 1.1 & -0.7 & 1.2 \\
\hline TDS $\left(\mathrm{mg} \mathrm{l}^{-1}\right)$ & 11.3 & 1456 & 213.5 & 134 & 332 & 301 & 198.1 & 3.1 & 1.2 & 0.9 \\
\hline ORP $(\mathrm{mV})$ & -95.6 & 499 & 140 & 9.0 & 127 & 119 & 79.5 & - & 1.1 & 1.9 \\
\hline Temperature $\left({ }^{\circ} \mathrm{C}\right)$ & 16.0 & 34.5 & 26.0 & 27.0 & 25.2 & 3.4 & 25.0 & 1.1 & -0.5 & 0.2 \\
\hline $\mathrm{DO}\left(\mathrm{mg} \mathrm{l}^{-1}\right)$ & 4.5 & 11.1 & 5.9 & 6.1 & 6.2 & 1.2 & 6.1 & 1.2 & 1.3 & 2.0 \\
\hline Fluoride $\left(\mathrm{mg} \mathrm{l}^{-1}\right)$ & $\leq 0.05$ & 6.3 & 0.36 & 0.05 & 0.48 & 0.6 & 0.3 & 2.9 & 5.1 & 36.4 \\
\hline Chloride $\left(\mathrm{mg} \mathrm{l}^{-1}\right)$ & 12.0 & 600 & 50.9 & 28.4 & 90.2 & 93.8 & 56.8 & 2.6 & 2.1 & 5.4 \\
\hline Nitrate $\left(\mathrm{mg} \mathrm{l}^{-1}\right)$ & 5.2 & 303 & 14.5 & 9.0 & 30.0 & 39.8 & 18.6 & 2.5 & 3.8 & 20.2 \\
\hline Sulphate $\left(\mathrm{mg} \mathrm{l}^{-1}\right)$ & 9.0 & 457 & 21.0 & 12.0 & 38.2 & 50.1 & 26.0 & 2.2 & 4.6 & 27.2 \\
\hline Phosphate $\left(\mathrm{mg} \mathrm{l}^{-1}\right)$ & 0.03 & 2.6 & 0.30 & 0.10 & 0.5 & 0.5 & 0.3 & 2.5 & 2.6 & 7.0 \\
\hline Uranium $\left(\mu \mathrm{g}^{-1}\right)$ & $\leq 0.2$ & 22.0 & 0.70 & 0.21 & 1.6 & 2.5 & 0.8 & 2.8 & 4.3 & 25.3 \\
\hline Hardness $\left(\mathrm{mg} \mathrm{l}^{-1}\right.$ as $\left.\mathrm{CaCO}_{3}\right)$ & 14 & 4070 & 148 & 56 & 213 & 272 & 143 & 2.4 & 7.5 & 92 \\
\hline Alkalinity $\left(\mathrm{mg} \mathrm{l}^{-1}\right.$ as $\left.\mathrm{CaCO}_{3}\right)$ & 12 & 711 & 125 & 90 & 164 & 117 & 117 & 2.5 & 0.7 & - \\
\hline
\end{tabular}

Table 5. Descriptive statistics of uranium and water quality parameters of groundwater samples

\begin{tabular}{|c|c|c|c|c|c|c|c|c|c|c|}
\hline Parameters & Minimum & Maximum & Median & Mode & Mean & $\begin{array}{l}\text { Standard } \\
\text { deviation }\end{array}$ & $\begin{array}{c}\text { Geometric } \\
\text { mean }\end{array}$ & $\begin{array}{c}\text { Geometric } \\
\text { SD }\end{array}$ & Skewness & Kurtosis \\
\hline $\mathrm{pH}$ & 4.2 & 9.9 & 7.3 & 7.2 & 7.3 & 0.6 & 7.3 & 1.1 & -0.4 & 1.0 \\
\hline TDS $\left(\mathrm{mg} \mathrm{l}^{-1}\right)$ & 2 & 10,703 & 379 & 15.0 & 525 & 545 & 338 & 2.8 & 3.7 & 26.8 \\
\hline ORP (mV) & -253 & 499 & 104 & 495 & 107 & 123 & - & - & 0.8 & 0.9 \\
\hline Temperature $\left({ }^{\circ} \mathrm{C}\right)$ & 16 & 38.4 & 29 & 30 & 28.8 & 2.7 & 28.7 & 1.1 & -0.5 & 1.6 \\
\hline $\mathrm{DO}\left(\mathrm{mg} \mathrm{l}^{-1}\right)$ & 2.2 & 11.1 & 4.1 & 3.2 & 4.3 & 1.5 & 4.1 & 1.4 & 0.9 & 0.6 \\
\hline Fluoride $\left(\mathrm{mg} \mathrm{l}^{-1}\right)$ & $\leq 0.05$ & 10.6 & 0.5 & 0.1 & 0.8 & 0.9 & 0.5 & 2.6 & 4.1 & 24.5 \\
\hline Chloride $\left(\mathrm{mg} \mathrm{l}^{-1}\right)$ & 6.5 & 6200 & 66 & 20 & 134 & 215 & 67.1 & 3.2 & 6.8 & 96.2 \\
\hline Nitrate $\left(\mathrm{mg} \mathrm{1}^{-1}\right)$ & 2.6 & 462 & 16.2 & 12 & 30.8 & 43.4 & 16.9 & 2.9 & 3.8 & 19.9 \\
\hline Sulphate $\left(\mathrm{mg} \mathrm{l}^{-1}\right)$ & 5.4 & 715 & 38 & 15 & 63.0 & 73.7 & 37.8 & 2.8 & 2.9 & 12.3 \\
\hline Phosphate $\left(\mathrm{mg} \mathrm{l}^{-1}\right)$ & 0.01 & 12 & 0.1 & 0.1 & 0.6 & 1.5 & 0.2 & 4.0 & 4.6 & 23.0 \\
\hline Uranium $\left(\mu \mathrm{g}^{-1}\right)$ & $\leq 0.2$ & 4918 & 1.9 & 0.2 & 6.8 & 40.4 & 2.1 & 4.2 & - & - \\
\hline Hardness $\left(\mathrm{mg} \mathrm{l}^{-1}\right.$ as $\left.\mathrm{CaCO}_{3}\right)$ & 12.6 & 6863 & 212 & 120 & 304 & 407 & 196 & 2.5 & 6.0 & 54 \\
\hline Alkalinity $\left(\mathrm{mg} \mathrm{l}^{-1}\right.$ as $\left.\mathrm{CaCO}_{3}\right)$ & 10.4 & 2187 & 192 & 200 & 223 & 170 & 160 & 2.5 & 1.4 & 3.5 \\
\hline
\end{tabular}

and checks. The quality of the data was also ensured by intercomparison exercise, spike recovery and cross method checking. The accuracy and precision of the LED fluorimeter were verified using certified standard and duplicate analysis and found to be within $\pm 5 \%$. Independent review of each of the participating laboratories was also conducted by a team of experts. Table 3 shows a comparison of different uranium analysis techniques.

\section{Results and discussion}

In the present study, data were broadly classified into surface and groundwater samples. The groundwater samples were segregated based on depth of water sources. The samples having values below detection limit were not considered for estimation of statistical parameters, to make them more conservative. Tables 4 and 5 provide descriptive statistics of water quality parameters and uranium values in surface and groundwater samples respectively. Hydrogeochemical variables are normally or log-normally distributed (such data are more common in geochemical database). The log-normal distribution is distinguished from normal distribution by its positive or negative skewness. Positive skewness is more prevalent in case of environmental data, because more data points are observed on the lower side; in this case, mean is higher than median, followed by mode. Similar pattern (mode $<$ median $<$ mean) was also observed in case of TDS, fluoride, chloride, nitrate, sulphate, uranium, hardness and alkalinity for both surface and groundwater (Figure 2). Moreover, skewness and kurtosis values, except for $\mathrm{pH}$ and temperature, indicated the positively skewed and leptokurtic distribution of data. Median is a more reasonable measure of central tendency for lognormally distributed data, whereas median is equal to the geometric mean ${ }^{36,37}$. The geometric mean and median of fluoride, chloride, nitrate, sulphate and uranium concentration in groundwater sources were statistically comparable. Therefore, it may be presumed that these variables are log-normally distributed. Figures 3 and 4 show the percentage frequency distribution of TDS and uranium, as well as fluoride and nitrate in groundwater samples respectively. From the figures, it may be observed that the distribution is positively skewed. 
RESEARCH ARTICLES

Table 6. Median concentration of water quality parameters and uranium in groundwater with depth of drinking water sources

\begin{tabular}{|c|c|c|c|c|c|c|c|c|c|c|c|c|c|}
\hline $\begin{array}{l}\text { Depth of } \\
\text { drinking } \\
\text { water source } \\
\text { (m) }\end{array}$ & $\mathrm{pH}$ & $\begin{array}{c}\text { TDS } \\
\left(\mathrm{mg} \mathrm{l}^{-1}\right)\end{array}$ & $\begin{array}{l}\text { ORP } \\
(\mathrm{mV})\end{array}$ & $\begin{array}{c}\text { Temperature } \\
\left({ }^{\circ} \mathrm{C}\right)\end{array}$ & $\begin{array}{c}\text { DO } \\
\left(\mathrm{mg} \mathrm{l}^{-1}\right)\end{array}$ & $\begin{array}{c}\text { Fluoride } \\
\left(\mathrm{mg} \mathrm{l}^{-1}\right)\end{array}$ & $\begin{array}{c}\text { Chloride } \\
\left(\mathrm{mg} \mathrm{l}^{-1}\right)\end{array}$ & $\begin{array}{l}\text { Nitrate } \\
\left(\mathrm{mg} \mathrm{l}^{-1}\right)\end{array}$ & $\begin{array}{l}\text { Sulphate } \\
\left(\mathrm{mg} \mathrm{l}^{-1}\right)\end{array}$ & $\begin{array}{l}\text { Phosphate } \\
\left(\mathrm{mg} \mathrm{l}^{-1}\right)\end{array}$ & $\begin{array}{l}\text { Uranium } \\
\left(\mu \mathrm{g}^{-1}\right)\end{array}$ & $\begin{array}{l}\text { Hardness } \\
\left(\mathrm{mg} \mathrm{l}^{-1} \text { as }\right. \\
\left.\mathrm{CaCO}_{3}\right)\end{array}$ & $\begin{array}{l}\text { Alkalinity } \\
\left(\mathrm{mg} \mathrm{l}^{-1} \text { as }\right. \\
\left.\mathrm{CaCO}_{3}\right)\end{array}$ \\
\hline$<2$ & 6.9 & 118 & 144 & 24 & 4.4 & 0.4 & 25.0 & 1.8 & 6.0 & 0.4 & 0.2 & 69 & 20 \\
\hline $2-5$ & 6.6 & 121 & 64 & 30 & 4.0 & 0.4 & 23.5 & 2.4 & 9.5 & 0.2 & 0.4 & 78 & 77 \\
\hline $5-10$ & 7.1 & 250 & 53 & 29 & 3.6 & 0.5 & 35.5 & 6.9 & 17.1 & 0.1 & 0.9 & 176 & 175 \\
\hline $10-20$ & 7.4 & 405 & 127 & 29 & 3.9 & 0.5 & 59.4 & 10.0 & 31.6 & 0.2 & 1.2 & 186 & 210 \\
\hline $20-40$ & 7.4 & 393 & 113 & 29 & 3.7 & 0.6 & 53.2 & 9.2 & 24.0 & 0.1 & 1.4 & 205 & 200 \\
\hline$>40$ & 7.4 & 416 & 110 & 29 & 3.8 & 0.5 & 80.0 & 13.0 & 33.1 & 0.1 & 1.4 & 248 & 210 \\
\hline
\end{tabular}

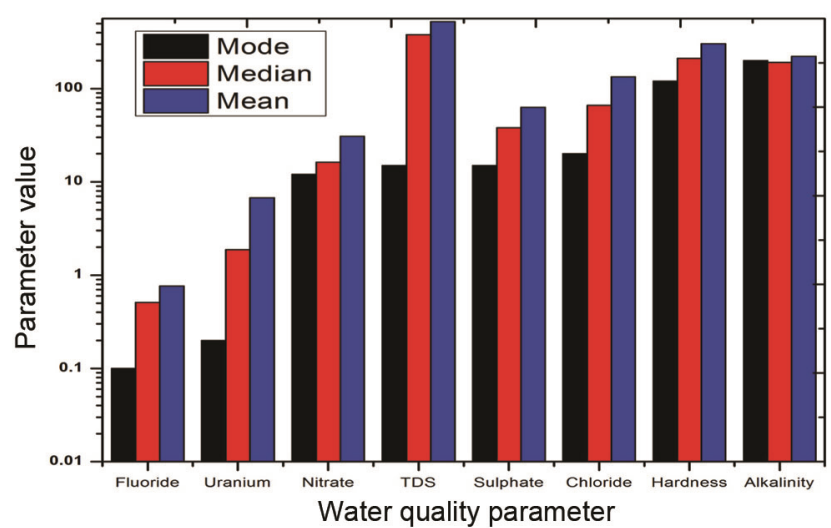

Figure 2. Variation of mean, median and mode of different water quality parameters.

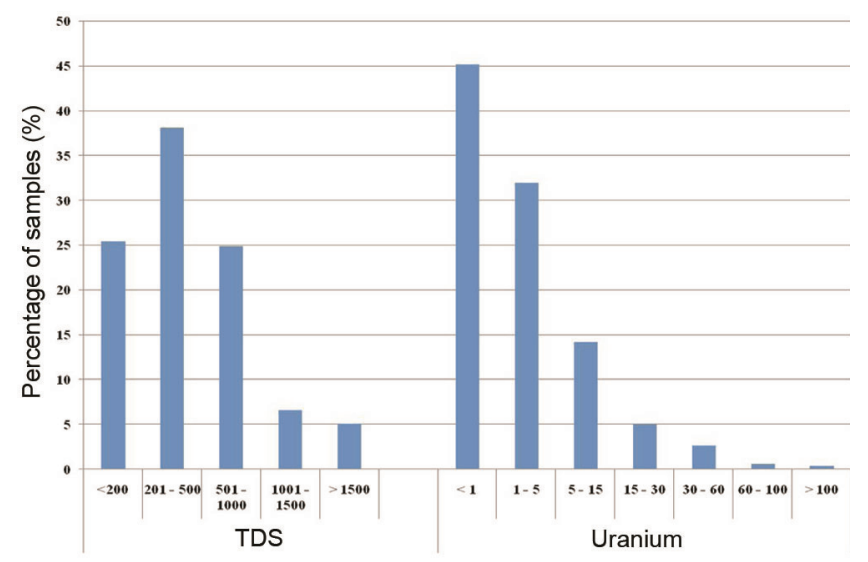

Figure 3. Percentage distribution of total dissolved solids (TDS) $\left(\mathrm{mg} \mathrm{l}^{-1}\right)$ and uranium $\left(\mu \mathrm{g} \mathrm{l}^{-1}\right)$ in groundwater.

From Table 4, it can be observed that the pH, TDS, hardness and alkalinity of the surface water samples vary in the range 5-8.6, 11-1456 and $14-4070 \mathrm{mg} \mathrm{l}^{-1}$ as $\mathrm{CaCO}_{3}$ and $12-711 \mathrm{mg} \mathrm{l}^{-1}$ as $\mathrm{CaCO}_{3}$ respectively. The above parameters have a median value of $7.5,214$, $148 \mathrm{mg} \mathrm{l}^{-1}$ as $\mathrm{CaCO}_{3}$ and $125 \mathrm{mg} \mathrm{l}^{-1}$ as $\mathrm{CaCO}_{3}$ respectively. The fluoride, chloride, sulphate and nitrate concentration varied in the range $\leq 0.05-6.3,12-600,9-457$ and 5.2-303 $\mathrm{mg} \mathrm{l}^{-1}$ with the median value of $0.36,50.9$, 21 and $14.5 \mathrm{mg} \mathrm{l}^{-1}$ respectively. Uranium concentration in surface water samples was found to be in the range $\leq 0.2-22 \mu \mathrm{g} \mathrm{l}^{-1}$ and all the values were well within the AERB stipulated limits ${ }^{38}$.

In groundwater samples, $\mathrm{pH}$, TDS, hardness and alkalinity were found to be in the range 4.2-9.9, 2-10,703 and $12.6-6863 \mathrm{mg} \mathrm{l}^{-1}$ as $\mathrm{CaCO}_{3}$ and $10.4-2187 \mathrm{mg} \mathrm{l}^{-1}$ as $\mathrm{CaCO}_{3}$, with the median value of $7.3,379$ and $212 \mathrm{mg} \mathrm{l}^{-1}$ as $\mathrm{CaCO}_{3}$ and $192 \mathrm{mg} \mathrm{l}^{-1}$ as $\mathrm{CaCO}_{3}$ respectively. The geometric mean and geometric standard deviation of uranium content in groundwater samples were estimated to be $2.1 \mu \mathrm{g} \mathrm{l}^{-1}$ and 4.2 respectively; the higher geometric standard deviation value was due to wide variation in its concentration. Generally, the observed variation in concentration of water quality parameters and uranium in surface water was less than that for groundwater samples.

About $36 \%, 30 \%, 26.5 \%, 6.2 \%$ and $5.2 \%$ of surface water samples exceeded the BIS recommended acceptable limits of $200 \mathrm{mg} \mathrm{l}^{-1}$ as $\mathrm{CaCO}_{3}$ for hardness, $200 \mathrm{mg} \mathrm{l}^{-1}$ as $\mathrm{CaCO}_{3}$ for alkalinity, $500 \mathrm{mg} \mathrm{l}^{-1}$ for TDS, $1 \mathrm{mg} \mathrm{l}^{-1}$ for fluoride and $45 \mathrm{mg} \mathrm{l}^{-1}$ for nitrate respectively ${ }^{39}$. In contrast, $51.6 \%, 45 \%, 36.3 \%, 20.5 \%$ and $14 \%$ of groundwater samples exceeded the BIS recommended acceptable limits for hardness, alkalinity, TDS, fluoride and nitrate respectively (Figure 5). About 2\% of groundwater samples exceeded the AERB prescribed limits for uranium with respect to radiological safety, while no surface water samples exceeded the limit.

Groundwater samples are classified according to the depth of water sources in the CGWB classification ${ }^{40}$. The median concentration of uranium and water quality parameters in groundwater with respect to the depth of water sources is given in Table 6 . Figure 6 shows the variation of TDS, chloride, sulphate, nitrate, hardness and alkalinity with depth. It may be observed that these parameters show a positive correlation with increasing depth of groundwater sources, which may be ascribed to long residence time, less recharge and greater rock-water interaction $^{41,42}$. Figure 7 shows the variation of uranium concentration with depth of groundwater sources in a box-whisker plot. This is the standard mode of displaying the distribution of data, in which the central rectangle depicts the first quartile to the third quartile (the interquartile range). A segment inside the rectangle 


\section{RESEARCH ARTICLES}

shows the median, and whiskers above and below the box show the locations of minimum and maximum. The higher and lower values beyond three times the inter quartile range are marked as outlier points. Uranium concentration was found to be in the range $\leq 0.2$ $46.2 \mu \mathrm{g} \mathrm{l}^{-1} \quad$ (median: $\leq 0.2 \mu \mathrm{g}^{-1}$ ), $\leq 0.2-144.4 \mu \mathrm{g}^{-1}$ (median: $0.4 \mu \mathrm{g}^{-1}$ ), $\leq 0.2-203 \mu \mathrm{g}^{-1}$ (median: $0.9 \mu \mathrm{g} \mathrm{l^{-1 }}$ ), $\leq 0.2-356.4 \mu \mathrm{g} \mathrm{l}^{-1}$ (median: $1.2 \mu \mathrm{g} \mathrm{l}^{-1}$ ), $\leq 0.2-4918 \mu \mathrm{g} \mathrm{l}^{-1}$ (median: $1.4 \mu \mathrm{g} \mathrm{l}^{-1}$ ) and $\leq 0.2-596 \mu \mathrm{g} \mathrm{l}^{-1}$ (median: $1.4 \mathrm{~g} \mathrm{l}^{-1}$ ) for $<2,2-5,5-10,10-20,20-40$ and $>40 \mathrm{~m}$ respectively. A positive association was observed between uranium concentration in groundwater and depth of water sources. This could be due to greater host rockwater interaction favouring more geogenic contamination with increasing depth. In majority of the cases sampled, uranium content was found to increase with depth of water sources. However, such observation cannot be generalized as the uranium-ion transfer process depends on local geochemistry ${ }^{41}$. Prediction of the occurrence and behaviour of uranium in groundwater is difficult since the geochemistry of uranium is complex, and function of multi-parameters and interlinked multi-process controlled release mechanism ${ }^{41}$.

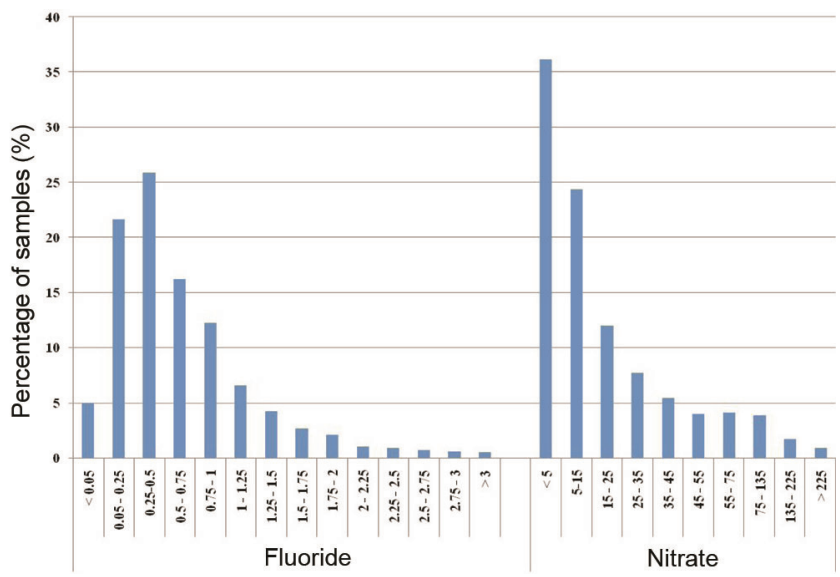

Figure 4. Percentage distribution of fluoride $\left(\mathrm{mg} \mathrm{l}^{-1}\right)$ and nitrate $\left(\mathrm{mg} \mathrm{l}^{-1}\right)$ in groundwater.

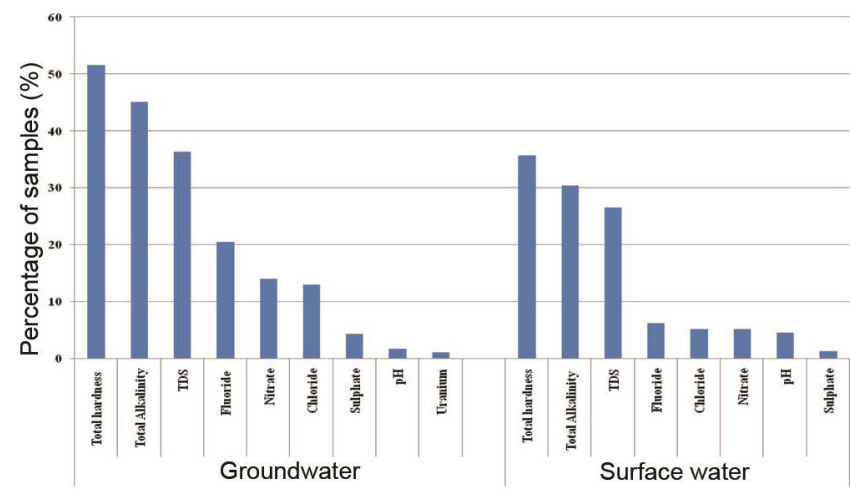

Figure 5. Percentage of groundwater and surface water samples higher than BIS limits.
Guideline values for uranium in drinking water in various countries are different and vary from $2 \mu \mathrm{g}^{-1}$ in Japan $^{43}$ to $964 \mu \mathrm{g}^{-1}$ in the Czech Republic ${ }^{44}$. Also, similar trend can be observed from the recommended guideline values prescribed by the World Health Organization (WHO) from $2 \mu \mathrm{g}^{-1}$ (in 1998) ${ }^{45}$ to $140 \mu \mathrm{g} \mathrm{l} \mathrm{l}^{-1}$ (in 1993) ( $^{46}$. Two approaches are adopted to derive the guideline values of uranium in drinking water, i.e. its chemical and radiological toxicity ${ }^{47,48}$. Moreover, regional, environmental, social, economic and cultural conditions are taken into consideration in the risk-benefit approach. In India, the guideline value for uranium in drinking water is derived on the basis of its radiotoxicity by the national regulatory body, viz. AERB ${ }^{38}$. Before 2004, the secondary limit of uranium in drinking water for nuclear facilities was based on the dose apportionment of the primary limit of $1 \mathrm{mSv} /$ year to members of the public (over and above natural background radiation $)^{49}$. The primary limit was apportioned as $50 \%$ from water intake route, $30 \%$ from air route and $20 \%$ from all other routes ${ }^{50}$. The apportionment for uranium was one-fifth through water route

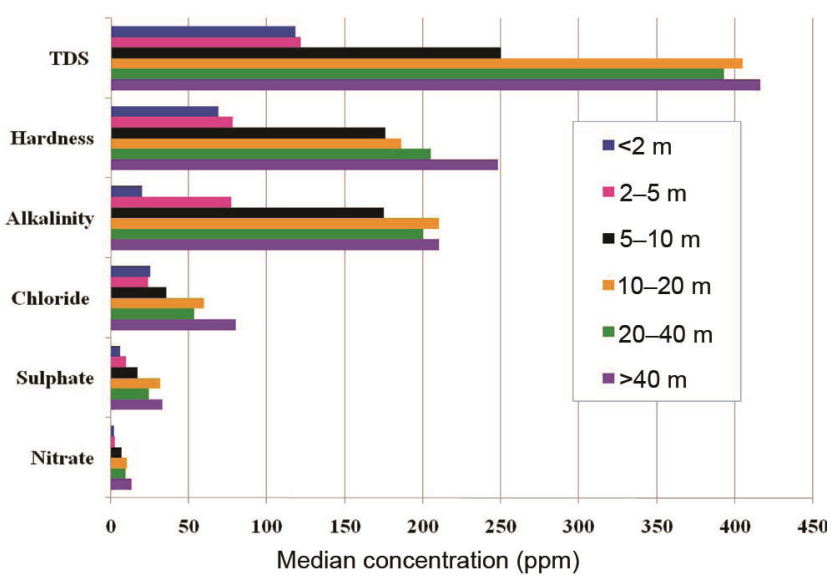

Figure 6. Variation of median concentration with depth of drinking water sources.

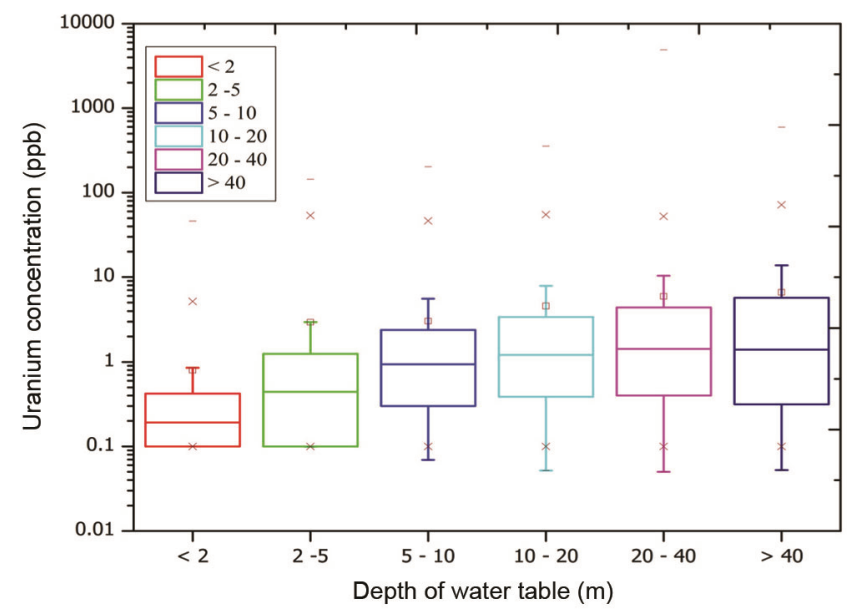

Figure 7. Box-and-whishker plot of uranium content with depth of water table.

CURRENT SCIENCE, VOL. 120, NO. 9, 10 MAY 2021 
$(0.1 \mathrm{mSv} / \mathrm{y})$. Assigning a value of $0.1 \mathrm{mSv} / \mathrm{y}$ from uranium through water route, the derived water concentration computed from the annual limit of intake value given in ICRP-61 works out to be $3 \mathrm{~Bq} / 1(100 \mu \mathrm{g} / \mathrm{l})$ for soluble compounds $^{51}$. In 2004 AERB, recommended the limit of uranium in drinking water to be $60 \mu \mathrm{g} \mathrm{l}^{-1}$ based on radiological toxicity and WHO criterion of $0.1 \mathrm{mSv} / \mathrm{y}$ maximum dose contribution for individual radionuclides through drinking water pathway and safety factor of 2 (ref. 38).

WHO recommends guideline values for chemical and radiological contaminants in drinking water. Guideline values for uranium are derived from both chemical and radiological toxicity. There is a large variation in guideline values over the years, which may be attributed to large uncertainty, extrapolation from animal studies at higher concentrations, lack of statistically significant correlation between adverse health effects and uranium in drinking water, etc. For example, WHO-recommended radiological guideline value for ${ }^{234} \mathrm{U}$ isotope was 4,10 and $1 \mathrm{~Bq} / 1$ in 1993, 2004 and 2017 respectively $^{46-48}$. There are many contradicting and conflicting reports on the adverse health effects due to ingestion of uranium through drinking water ${ }^{5,7}$.

\section{Remedial measures}

Various water treatment techniques such as coagulation/ filtration, lime softening, ion exchange, nanofiltration, reverse osmosis, activated charcoal adsorption, zero valent iron are in practice for the removal of uranium in different countries ${ }^{52-59}$. Reverse osmosis is one of the latest membrane-based technologies, used in waterpurification systems for removal of uranium. BARC has carried out studies on the removal of uranium in drinking water using hybrid membrane technique ${ }^{60}$. Field studies are also being carried out in a few districts of Punjab, based on RO technique at village level to provide potable water.

\section{Conclusion}

Uranium and water quality parameters are observed to be positively skewed. The median and geometric mean values of most of the analysed parameters are found to be comparable, indicating log-normal distribution of the data. Distribution of uranium content and water quality parameters is highly heterogeneous, signifying the influence of the underlying regional geology and geochemistry. Divergent uranium guideline values in different countries may be attributed to the lack of statistically significant data on health effects and their large uncertainties. Therefore, a comprehensive study on health effects due to ingestion of uranium through drinking water is required considering the risk-benefit approach, local environment and socio-economic conditions. In the present study, about half of the total land area of India has been covered and efforts are being made to complete the uranium mapping. The findings will be helpful in identifying hotspots in water resources in the country with respect to uranium. Furthermore, they will also be helpful in longterm planning/management of water resources in India and enable the formulation of future guidelines on uranium and other water quality parameters by the regulatory authorities and governing institutions.

1. World Bank report, Deep wells and prudence, towards pragmatic action for addressing ground water overexploitation in India, World Bank, USA, 2010.

2. CGWB, National compilation on dynamic ground water resources of India, 2017. Government of India (GoI), Ministry of Jal Shakti, Department of Water Resources, River Development and Ganga Rejuvenation, Central Ground Water Board, July 2019.

3. CGWB, Concept note on geogenic contamination of ground water in India. Central Ground Water Board, Ministry of Water Resources, GoI, 2014.

4. Tripathi, R. M., Sahoo, S. K., Mohapatra, S., Lenka, P., Dubey, J. S. and Puranik, V. D., Study of uranium isotopic composition in groundwater and deviation from secular equilibrium condition. J. Radioanal. Nucl. Chem., 2013, 295, 1195-1200; doi:10.1007/ s10967-012-1992-7.

5. UNSCEAR, Sources and effects of ionizing radiation. United Nations Scientific Committee on the Effect of Atomic Radiation, Annex D-Biological effects of selected internal emitters Uranium, United Nations, New York, USA, 2016.

6. Odette, P., Thomas, V., Eric, A., Pascal, F., Pascale, P., Paivi, K. and Laina, S., Uranium speciation in drinking water from drilled wells in southern Finland and its potential links to health effects. Environ. Sci. Technol., 2009, 43, 3941-3946.

7. WHO, Uranium in drinking water. Background document for development of WHO guidelines for drinking-water quality, World Health Organization, Geneva, 2012.

8. Liesch, T., Hinrichsen, S. and Goldscheider, N., Uranium in groundwater - fertilizer versus geogenic sources. Sci. Total Environ., 2015, 536, 981-995.

9. Woosik, S. et al., Distribution and potential health risk of groundwater uranium in Korea. Chemosphere, 2016, 163, 108-115.

10. Stalder, E., Blanc, A. and Haldimanr, A., Occurrence of uranium in Swiss drinking water. Chemosphere, 2012, 86, 672-679.

11. Berisha, F. and Goessler, W., Uranium in Kosovo's drinking water. Chemosphere, 2013, 93, 2165-2170.

12. Nolan, J. and Weber, K. A., Natural uranium contamination in major US aquifers linked to nitrate. Environ. Sci. Technol. Lett., 2015, 2, 215-220.

13. Babu, M. N. S., Somashekar, R. K., Kumar, S. A., Shivanna, K., Krishnamurthy, V. and Eappen, K. P., Concentration of uranium levels in groundwater. Int. J. Environ. Sci. Technol., 2008, 5(2), 263.

14. Singh, J., Singh, L. and Singh, G., High U-contents observed in some drinking waters of Punjab, India. J. Environ. Radioact., 1995, 26, 217-222.

15. Sinha, D. K., Srivastava, P. K., Hansoti, S. K. and Sharma, P. K., Uranium and radon concentration in groundwater of Deccan Trap country and environmental hazard in Keolari-Nainpur area, SeoniMandla district, Madhya Pradesh. Geol. Surv. India Spec. Publ., 1997, 48(2), 115-121.

16. Coyte, R. M., Jain, R. C., Srivastava, S. K., Sharma, K. C., Khalil, A., Ma, L. and Venhosh, A., Large-scale uranium contamination of groundwater resources in India. Environ. Sci. Technol. Lett., 2018, 5(6), 341-347.

17. IUGS, A global geochemical database for environmental and resource management. Recommendations for International 


\section{RESEARCH ARTICLES}

geochemical mapping final report of IGCP Project 259, International Union of Geological Sciences, 2005.

18. ISO 5667-1, Water quality. Sampling. Guidance on the design of sampling programmes and sampling techniques, 2006.

19. ISO 5667-3, Water quality - Sampling - part 3: preservation and handling of water samples, 2018.

20. ISO 5667-14, Water quality. Sampling. Guidance on quality assurance and quality control of environmental water sampling and handling, 2016.

21. IS 3025-1, Methods of sampling and test (physical and chemical) for water and waste water, part 1 - Sampling, 1987.

22. IS 3025-11, Methods of sampling and test (physical and chemical) for water and wastewater, part 11: $\mathrm{pH}$ value, 1983 .

23. IS 3025-16, Methods of sampling and test (physical and chemical) for water and wastewater, part 16: filterable residue (total dissolved solids), 1984.

24. IS 3025-9, Methods of sampling and test (physical and chemical) for water and wastewater, Part 9: temperature, 1984.

25. CPCB, Guidelines for water quality monitoring, Central Pollution Control Board, Delhi, MINARS/27/2007-08, 2008.

26. APHA, Standard Methods for Examination of Water and Waste Waters, American Public Health Association, Washington DC, 2005, 21st edn.

27. Manual of LED Fluorimeter, Quantalase Enterprises Pvt Ltd Indore, 2015.

28. Sahoo, S. K. et al., Distribution of uranium in drinking water and associated age-dependent radiation dose in India. Radiat. Prot. Dosim., 2009, 136(2), 108-113.

29. Sahoo, S. K., Mohapatra, S., Patra, A. C., Sumesh, C. G., Jha, V. N., Tripathi, R. M. and Puranik, V. D., Determination of uranium at ultra trace level in packaged drinking water by laser fluorimeter and consequent ingestion dose. Radioprotection, 2010, 45, 55-66.

30. IS 3025-21, Methods of sampling and test (physical and chemical) for water and wastewater, part 21: total hardness, 2009.

31. IS 3025-23, Methods of sampling and test (physical and chemical) for water and wastewater, part 23: alkalinity, 1986.

32. IS 3025-24, Methods of sampling and test (physical and chemical) for water and wastewater, part 24: sulphates, 1986.

33. IS 3025-32, Methods of sampling and test (physical and chemical) for water and wastewater, part 32: chloride, 1988.

34. IS 3025-31, Methods of sampling and test (physical and chemical) for water and wastewater, part 31: phosphorus, 1988.

35. IS 3025-34, Methods of sampling and test (physical and chemical) for water and wastewater, part 34: nitrogen, 1988.

36. Shih, W. J. and Binkowitz, B., Median versus geometric mean for lognormal samples. J. Stat. Comput. Simul., 1987, 28(1), 81-83.

37. Blackwood, L. G., The lognormal distribution, environmental data and radiological monitoring. Environ. Monit. Assess., 1992, 21, $193-210$.

38. Sahoo, S. K., Jha, V. N., Patra, A. C., Jha, S. K. and Kulkarni, M. S., Scientific background and methodology adopted on derivation of regulatory limit for uranium in drinking water - a global perspective. J. Environ. Adv., 2020, 2, 100020; doi.org/10.1016/ j.envadv.2020.100020.

39. IS 10500 , Indian standard drinking water - Specification, Second revision, May 2012.

40. CGWB, 2018, Ground Water Year Book - India 2017-18, Central Ground Water Board, Ministry of Water Resources, River Development and Ganga Rejuvenation, GoI, Faridabad, 2018.

41. Riedel, T. and Kubeck, C., Uranium in groundwater - a synopsis based on a large hydrogeochemical data set. Water Res., 2018, 129, 29-38.

42. Jurgens, B. C., Fram, M. S. F., Belitz, K., Burow, K. R. and Landon, M. K., Effects of groundwater development on uranium: Central Valley, California, USA. Ground Water, 2010, 48(6), 913-928.

43. Wakayama, H., Revision of drinking water quality standards in Japan, Office of Drinking Water Quality Management, Water
Supply Division, Health Service Bureau, Ministry of Health, Labour and Welfare, Japan, 2004.

44. Scientific opinion of the Panel on Contaminants in the Food Chain on a request from German Federal Institute for Risk Assessment on uranium in foodstuff, in particular mineral water. EFSA J., 2009, 1018, 1-59.

45. WHO, Guidelines for drinking-water quality. Addendum to volume 2, Health criteria and other supporting information, World Health Organization, Geneva, 1998, 2nd edn.

46. WHO, Guidelines for drinking-water quality. World Health Organization, Geneva, 1993, 2nd edn.

47. WHO, Guidelines for drinking-water quality. World Health Organization, Geneva, 2004, 3rd edn.

48. WHO, Guidelines for drinking-water quality. World Health Organization, Geneva, 2017, 4th edn.

49. IAEA, International basic safety standards for protection against ionizing radiation and for the safety of radiation sources, International Atomic Energy Agency, Vienna, IAEA Safety Series no. 115, 1996.

50. Raghavayya, M., Secondary limits of exposure in facilities handling uranium. BARC Report No. BARC/1999/E/020, 1999.

51. ICRP-61, Annual limits on intake of radionuclides by workers based on the 1990 recommendations, ICRP Publication 61, Annals of the ICRP 21(4), 1991.

52. Jimenez, A. and Rufo, M. D. L. M., Effect of water purification on its radioactive content. Water Res., 2002, 36, 1715-1724.

53. Coleman, S. J., Coronado, P. R., Maxwell, R. S. and Reynolds, J. G., Granulated activated carbon modified with hydrophobic silica aerogelpotential composite materials for the removal of uranium from aqueous solutions. Environ. Sci. Technol., 2003, 37(10), 2286-2290.

54. Bostick, W. D., Jarabek, R. J., Bostick, D. A. and Conca, J., Phosphate-induced metal stabilization: use of apatite and bone char for the removal of soluble radionuclides in authentic and simulated DOE groundwaters. Adv. Environ. Res., 1999, 3, 488-498.

55. Gerente, C., Andres, Y. and Le Cloirec, P., Uranium removal onto chitosan: competition with organic substances. Environ. Technol., 1999, 20, 515-521.

56. Farrell, J., Bostic, W. D., Jarabek, R. J. and Fiedor, J. N., Uranium removal from ground water using zero valent iron media. Ground Water, 1999, 37(4), 618-624.

57. Morrison, S. J., Metzler, D. R. and Dwye, B. P., Removal of As, $\mathrm{Mn}, \mathrm{Mo}, \mathrm{Se}, \mathrm{U}, \mathrm{V}$ and $\mathrm{Zn}$ from groundwater by zero-valent iron in a passive treatment cell: reaction process modeling. J. Contam. Hydrol., 2003, 56, 99-116.

58. Abdelouas, A., Lutze, W., Nuttall, E. and Gong, W., Remediation of U (VI)-contaminated water using zero-valent iron. Earth Planet. Sci., 1999, 328, 315-319.

59. Raff, O. and Wilken, R. D., Removal of dissolved uranium by nanofiltration. Desalination, 1999, 122, 147-150.

60. Triptathi, R. M. et al., Removal of uranium in water by hybrid membrane technique, BARC Internal Report: BARC/2012/I/016, 2012.

ACKNOWLEDGEMENTS. We thank the Board of Research in Nuclear Sciences (BRNS), India for providing funds for this study. We thank Dr Srikumar Banerjee (Chairman, BRNS, DAE) for motivation and support during the course of this work; all the Principal Investigators, Co-Principal Investigators, Junior Research Fellows, Principal Collaborators and Co-Principal Collaborators for their help in collecting and analysing water samples during the study. We thank our colleagues at the Health Physics Division, BARC, Mumbai for support.

Received 1 December 2020; revised accepted 3 February 2021

doi: $10.18520 / \mathrm{cs} / \mathrm{v} 120 / \mathrm{i} 9 / 1482-1490$ 